\title{
KARAKTERISASI BEBERAPA STRAIN GURAMI Osphronemus gouramy Lac. MENGGUNAKAN MARKA RAPD
}

\author{
Anisa Kartika Sari, Agus Nuryanto, Agus Hery Susanto
}

Fakultas Biologi, Universitas Jenderal Soedirman, Jalan dr. Suparno 63 Purwokerto 53122

\section{A B S T R A C T}

Giant gouramy, Osphronemus gouramy Lac. is a popular fish species in Indonesia, especially in Java and Sumatera as this freshwater fish species has a high economic value of stable price. Fish farmers in Bogor divide giant gouramy into six strains based on egg productivity, growth rate, and maximum weight of the adult. They are soang, jepang, blue saphire, paris, bastar, and porselin. These various strains lead to the need of study on the genetic relationship among them, which can be performed by the use of RAPD (Random Amplified Polymorphic DNA) marker. This study aims to determine primers producing consistent and polymorphic RAPD markers, determine specific RAPD markers, and know the genetic relationship among several giant gouramy strains. The strains used in this study are soang, jepang, and blue saphire. Survey method was applied employing purposive random sampling technique. Total genomic DNA was isolated using Genjet tm $^{\mathrm{m}}$ genomic DNA purification kit (Fermentas), which was then used as template to amplify RAPD markers with primers OPA07, OPA-09, OPA-11, OPA-20, OPAH-01, OPAH-08, OPAH-09, and OPAC-14. The variables examined were patterns and numbers of specific DNA fragments as the PCR amplification products. Selected primers were determined descriptively on the basis of specific DNA bands appearing on the agarose gel. Genetic diversity was predetermined by changing qualitative band pattern into quantitative binnary data. Genetic relationship was analyzed using cladistic method with PAUP software. The results showed that only five of the eight primers produce consistent and polymorphic RAPD markers, i.e. OPA-11, OPA-20, OPAH-1, OPAH-8, and OPAH-9. Specific RAPD markers which can be used to distinguish several gouramy strains are those amplified with OPA-20 of $786 \mathrm{bp}$, OPA-20 of 1,176 bp, OPAH-8 of 1,000 bp and OPAC-14 of 1,607 bp. Nervertheless, it was found that RAPD markers cannot be used to clearly determine genetic relationship among gouramy strains.

KEY WORDS: Osphronemus gouramy, genetic relationship, RAPD

Penulis korespondensi: ANISA KARTIKA SARI | email: anissa_fabio@yahoo.com

\section{PENDAH UL UAN}

Ikan gurami merupakan ikan konsumsi yang sangat populer bagi masyarakat Indonesia, khususnya di Jawa dan Sumatera. Menurut Iwan (2006), ikan budidaya air tawar tersebut memiliki nilai ekonomi tinggi dengan harga yang stabil. Dalam upaya peningkatan produksi ikan gurami, Kementerian Kelautan dan Perikanan (2010) menyatakan perlunya dilakukan penelitian tentang gurami, terutama yang terkait dengan aspek kualitas genetiknya.

Sitanggang dan Sarwono (2007) menyatakan bahwa petani gurami di Bogor membedakan enam strain gurami berdasarkan daya produksi telur, kecepatan tumbuh, dan ukuran atau bobot maksimal gurami dewasa. Keenam strain tersebut adalah soang, jepang, blue saphire, paris, bastar, dan porselin. Namun, pada penelitian ini hanya digunakan tiga strain ikan gurami sebagai bahan penelitian, yaitu soang, jepang, dan blue saphire.

Menurut Kottelat et al. (1993), klasifikasi ikan gurami adalah sebagai berikut.

$\begin{array}{ll}\text { Filum } & \text { : Chordata } \\ \text { Klasis } & \text { : Pisces } \\ \text { Ordo } & \text { : Perciformes } \\ \text { Subordo } & \text { : Anabantoidei } \\ \text { Familia } & \text { : Osphronemidae } \\ \text { Genus } & \text { : Osphronemus } \\ \text { Spesies } & \text { : Osphronemus gouramy Lac. }\end{array}$

Beranekaragamnya strain ikan gurami mendorong perlunya dilakukan penelitian mengenai hubungan kekerabatan di antara strain-strain tersebut. Hal ini karena informasi tentang hubungan kekerabatan antar strain dapat memberikan landasan bagi strategi penyilangan yang akan dilakukan. Allard (1960) menyatakan bahwa persilangan antarindividu yang berkerabat dekat dapat mengakibatkan penurunan kualitas genetik berupa vigor individu hasil persilangan yang lemah dengan ukuran yang lebih kecil daripada tetuanya, kurang subur, dan bahkan mengalami cacat genetik.

Studi hubungan kekerabatan genetik dapat dilakukan menggunakan marka (penanda) molekuler, antara lain berupa RAPD (Random Amplified Polymorphic DNA). Jain et al. (1994) menjelaskan bahwa marka RAPD dapat digunakan untuk merekonstruksi hubungan kekerabatan genetik pada populasi dengan cepat dan akurat sehingga dapat membantu pemilihan tetua dalam persilangan.

Teknik RAPD merupakan teknik molekuler yang berbasis PCR. RAPD dapat digunakan untuk mendeteksi polimorfisme ruas nukleotida pada DNA dengan memanfaatkan primer tunggal yang memiliki urutan nukleotida acak. Primer tersebut akan menempel secara acak pada DNA genom. Segmen DNA genom yang mengalami penempelan primer akan diamplifikasi menggunakan siklus termal melalui teknik PCR sehingga dihasilkan sejumlah fragmen DNA tertentu yang merupakan marka RAPD (Welsh dan McClleland, 1990; Williams et al., 1990). William et al. (1996) juga menyebutkan bahwa inisiasi amplifikasi DNA oleh enzim DNA polimerase memerlukan primer oligonukleotida, yang biasanya berukuran 9 hingga 20 basa. Berdasarkan uraian tersebut di atas, penelitian ini bertujuan untuk menentukan primer oligonukleotida yang dapat 
menghasilkan marka RAPD yang konsisten dan polimorfik pada beberapa strain ikan gurami, menentukan marka RAPD spesifik untuk beberapa strain ikan gurami, dan mengetahui hubungan kekerabatan genetik di antara beberapa strain ikan gurami.

\section{METODE}

Metode yang digunakan adalah survei dengan teknik pengambilan sampel secara purposive random sampling, yaitu pengambilan sampel secara acak pada daerah yang telah ditentukan. Jaringan sirip ekor ikan gurami dipotong dengan ukuran kurang lebih $5 \mathrm{~mm}$. Sampel diawetkan dalam alkohol 96\% PA, kemudian disimpan pada suhu $4^{\circ} \mathrm{C}$ hingga analisis DNA dilakukan.

Genom (DNA) total diisolasi menggunakan metode Genjet $^{\mathrm{TM}}$ genomic DNA purification kit (fermentas). Sampel diinkubasi pada suhu $60^{\circ} \mathrm{C}$ dengan kecepatan $1.000 \mathrm{rpm}$ selama 4-6 jam. Sampel diresuspensi dengan menambahkan $180 \mu \mathrm{L}$ digestion solution. $20 \mu \mathrm{L}$ proteinase $\mathrm{K}$ dicampurkan ke dalam sampel dan dilakukan inkubasi pada suhu $56^{\circ} \mathrm{C}$ selama 1-3 jam untuk sampel berukuran $5 \mathrm{mg}$ atau 6 jam untuk sampel lebih dari $5 \mathrm{mg}$. Sebanyak $20 \mu \mathrm{L}$ RNAse A dicampurkan ke dalam sampel dan diinkubasi selama 10 menit pada suhu ruang. $200 \mu \mathrm{L}$ lysis solution dicampurkan ke dalam sampel hingga rata, diikuti dengan penambahan $400 \mu \mathrm{L}$ etanol $50 \%$ ke dalam sampel dan dihomogenkan. Sampel ditransfer ke dalam Genjet ${ }^{\mathrm{TM}}$ purification column dan dimasukkan ke dalam tabung koleksi, kemudian disentrifugasi pada kecepatan $9.000 \mathrm{rpm}$ selama 1 menit. Cairan yang tertampung di dalam tabung koleksi kemudian dibuang. Column dikembalikan ke tabung koleksi dan ditambahkan $500 \mu \mathrm{L}$ wash buffer I yang telah diencerkan menggunakan alkohol absolut PA. Larutan disentrifugasi selama 1 menit pada kecepatan 11.000 rpm. abung koleksi yang berisi larutan wash buffer I diganti dengan yang baru. $500 \mu \mathrm{L}$ bufer pencuci II dtambahkan ke dalam tabung purification column dan dilakukan sentrifugasi selama 3 menit pada kecepata» 12.000 x g. Purification column dibuang beserta larutan yang ada di dalamnya. Selanjutnya, $200 \mu \mathrm{L}$ eluton buffer dimasukkan ke dalam tabung koleksi baru dan diinkubasi selama 2 menit, kemudian disentrifugasi selama 1 menit pada kecepatan $11.000 \mathrm{rpm}$. Larutan disimpan di dalam tabung mikrosentrifuga $1,5 \mathrm{~mL}$ pada suhu $-20^{\circ} \mathrm{C}$.

Volume total campuran reaksi PCR yang digunakan untuk amplifikasi marka RAPD ialah $25 \mu \mathrm{L}$. Larutan campuran tersebut terdiri atas bufer PCR 10x sebanyak 2,5 $\mu \mathrm{L}$, dNTP sebanyak $2 \mu \mathrm{L}$, primer $1 \mu \mathrm{L}$, Taq DNA polimerase $0,15 \mu \mathrm{L}$, dan ditambahkan $\mathrm{ddH}_{2} \mathrm{O}$ hingga $25 \mu \mathrm{L}$ (Muneer et al., 2009). Kontrol negatif berupa campuran PCR tanpa DNA templat. Pradenaturasi dilakukan selama 3 menit pada suhu $94^{\circ} \mathrm{C}$. PCR dilakukan sebanyak 45 siklus, yang masingmasing terdiri atas denaturasi selama 1 menit pada suhu $94^{\circ} \mathrm{C}$, penempelan primer selama 45 detik pada suhu $38^{\circ} \mathrm{C}$, dan pemanjangan primer selama 1,5 menit pada suhu $72^{\circ} \mathrm{C}$. Tahap pemanjangan akhir dilakukan selama 5 menit pada suhu $72^{\circ} \mathrm{C}$ (Muneer et al., 2009). Produk amplifikasi selanjutnya divisualisasikan menggunakan teknik elektroforesis gel agarosa untuk dilakukan analisis terhadap pola pita yang muncul.

Penentuan primer terpilih dilakukan secara deskriptif berdasarkan ada tidaknya pita DNA spesifik pada gel agarosa. Penentuan keanekaragaman genetik diawali dengan mengubah pola pita RAPD yang bersifat kualitatif menjadi data biner kuantitatif. Hubungan kekerabatan genetik dianalisis menggunakan metode kladistik dengan bantuan piranti lunak PAUP versi 4.0bv10.

\section{HASIL DAN PEMBAHASAN}

Secara keseluruhan dapat dikatakan bahwa DNA dari tiap individu sampel berhasil diisolasi walaupun beberapa di antaranya smear. Namun demikian, DNA hasil isolasi tersebut masih dapat digunakan untuk proses berikutnya, yaitu amplifikasi marka RAPD menggunakan teknik PCR. Hal ini karena amplifikasi marka RAPD akan berlangsung secara acak, tidak harus terjadi pada daerah tertentu saja.

Kondisi PCR optimal yang diperoleh selama penelitian adalah pradenaturasi selama 3 menit pada suhu $94^{\circ} \mathrm{C}$. Selanjutnya, PCR dilakukan sebanyak 45 siklus, masing-masing terdiri atas denaturasi selama 1 menit pada suhu $94^{\circ} \mathrm{C}$, penempelan primer selama 45 detik pada suhu $38^{\circ} \mathrm{C}$, dan pemanjangan primer selama 1,5 menit pada suhu $72^{\circ} \mathrm{C}$. Tahap pemanjangan akhir dilakukan selama 5 menit pada suhu $72^{\circ} \mathrm{C}$.

Beberapa marka RAPD spesifik yang dapat digunakan untuk membedakan antarstrain ikan gurami di antaranya ialah marka RAPD dari primer OPA-20 ukuran 786 pb yang hanya muncul pada strain gurami soang, marka RAPD dari primer OPA-20 ukuran $1.176 \mathrm{pb}$ yang hanya muncul pada gurami strain jepang dan strain soang, marka RAPD dari primer OPAH-08 ukuran 1.000 pb yang hanya muncul pada gurami strain jepang dan strain soang, dan marka RAPD dari primer OPAC-14 ukuran $1.607 \mathrm{pb}$ yang hanya muncul pada gurami strain jepang dan strain soang.

Keanekaragaman genetik dapat ditentukan oleh nilai rata-rata heterozigositas dan persentase lokus polimorfik (Asih et al., 2006 dalam Lestari, 2011). Analisis keanekaragaman genetik pada penelitian ini menunjukkan bahwa ke-15 marka RAPD yang diperoleh memiliki polimorfisme sebesar 68,75\%.

Berdasarkan Tabel 1., ditemukan lima primer yang dapat menghasilkan marka RAPD yang konsisten dan polimorfik pada beberapa strain ikan gurami, yaitu OPA-11, OPA-20, OPAH-01, OPAH-08, dan ОРАН-09. Primer-primer tersebut dipilih karena seluruhnya memiliki nilai polimorfisme 100\%. Untuk menganalisis hubungan kekerabatan genetik antarstrain ikan gurami tersebut digunakan software PAUP versi 4.0bv10. Data biner hasil amplifikasi sampel gurami dijadikan sebagai in-group, sedangkan data outgroup yang akan digunakan sebagai pembanding didapatkan dari data biner hasil amplifikasi sampel DNA ikan sepat (Trichogaster trichopterus) (Lestari, 2011).

Pada proses analisis data yang menggunakan PAUP software hanya diambil 17 individu dari total 24 individu, antara lain dua individu dari strain blue saphire, lima individu dari strain jepang serta sepuluh individu dari strain soang. Sampel yang diambil hanya 17 karena dari 24 sampel individu ada beberapa strain yang tidak termasuk dalam strain yang akan diteliti hubungan kekerabatannya seperti strain sabah. Beberapa individu lainnya juga ada yang tidak 
diteliti karena diduga terjadi kesalahan pada saat mengidentifikasi jenis strain tersebut sehingga untuk mempermudah analisis data hanya digunakan 17 sampel individu.

Tabel 1. Primer terpilih dan polimorfisme marka RAPD teramplifikasi pada sampel Osphronemus gouramy

\begin{tabular}{cccccc}
\hline Primer & $\begin{array}{c}\text { Jumlah Marka } \\
\text { Teramplifikasi }\end{array}$ & $\begin{array}{c}\text { Jumlah Pita per } \\
\text { Individu }\end{array}$ & $\begin{array}{c}\text { Jumlah Marka } \\
\text { Monomofik }\end{array}$ & $\begin{array}{c}\text { Jumlah Marka } \\
\text { Polimorfik }\end{array}$ & Polimorfisme (\%) \\
\hline OPA-07 & 1 & 1 & 1 & 0 & 0 \\
OPA-09 & 1 & 1 & 1 & 0 & 0 \\
OPA-11 & 2 & $0-3$ & 0 & 2 & 100 \\
OPA-20 & 3 & $0-4$ & 0 & 3 & 100 \\
OPAH-01 & 1 & $0-1$ & 0 & 2 & 100 \\
OPAH-08 & 2 & $0-2$ & 0 & 3 & 100 \\
OPAH-09 & 3 & $0-3$ & 0 & 1 & 50 \\
OPAC-14 & 2 & $0-2$ & 1 & 11 & $68,75 \%$ \\
Total & 15 & - & 4 & & 0 \\
\hline
\end{tabular}

Pohon filogenetik yang dihasilkan dari analisis piranti lunak PAUP versi $4.0 \mathrm{bv} 10$ (Gambar 1) menunjukan bahwa ikan gurami dan ikan sepat terbagi menjadi dua kelompok monofiletik yang terpisah satu sama lain. Kelompok monofiletik yang pertama merupakan outgroup, yaitu spesies ikan sepat, sedangkan kelompok monofiletik yang kedua ialah in-group, yaitu spesies Osphronemus gouramy.

Namun, jika dilihat lebih lanjut pada Gambar 1., antarstrain gurami tidak terlihat adanya pembagian sub-clade yang jelas. Hal tersebut karena pada setiap sub-clade terdapat individu-individu yang berasal dari strain berbeda, yang membuktikan adanya percampuran antar strain. Percampuran antarstrain diduga disebabkan oleh marka RAPD tidak cukup baik untuk digunakan dalam identifikasi pada level strain tetapi cukup baik untuk analisis keanekaragaman genetik dalam populasi. Terbatasnya kemampuan marka RAPD dalam mengidentifikasi hubungan kekerabatan genetik pada level strain diduga karena terbatasnya urutan sekuens primer sehingga masih menyisakan daerah genom yang tidak terdeteksi variasi gennya pada level strain. Dodgson et al. (1997) menyatakan bahwa teknik RAPD memiliki tingkat reliabilitas yang rendah tetapi memiliki tingkat kecepatan pengujian yang cukup tinggi.

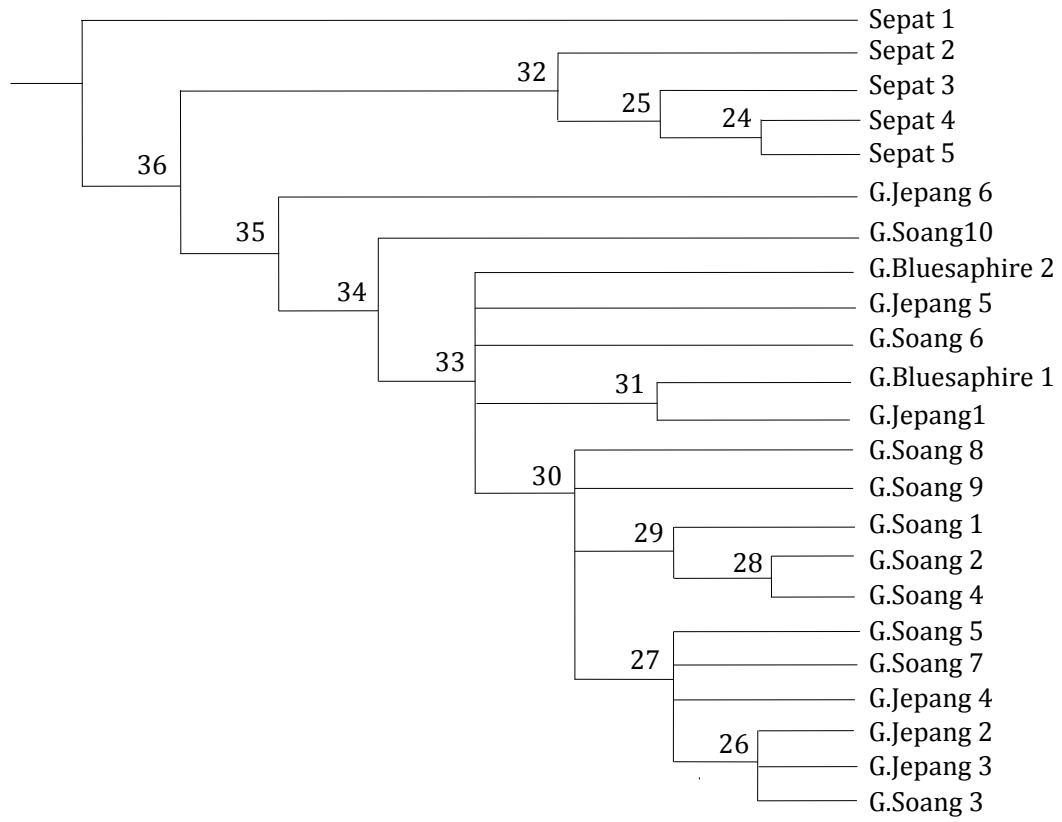

Gambar 1. Kladogram hubungan filogenetik antarstrain Osphronemus gouramy Lac.

Menurut 0' Brien (1991) dalam Dodgson et al. (1997), marka RAPD termasuk dalam tipe fingerprinting marker. Pada penanda molekuler jenis ini tidak diperlukan informasi urutan sekuens fragmen DNA yang akan digandakan. Dodgson et al. (1997) juga mengemukakan terdapat sembilan jenis penanda molekuler, yaitu RFLP (Restriction Fragmen Length Polymorphism), SSR (Simple Sequence Repeats) atau mikrosatelit, STS (Sequence Tagged-Site), EST (Expressed Sequence Tag), RAPD (Random Amplified
DNA), VNTR (Variable Number of Tandem Repeats) atau minisatelit, CR-1 (Chicken Repeat 1-based marker), AFLP (Amplified Fragment Length Polymorphism) dan RLGS (Restriction Landmark Genomic Scanning).

Berdasarkan kladogram pada Gambar 1, diduga bahwa gurami strain bluesaphire nomor 1 dan gurami strain jepang nomor 1 memiliki hubungan kekerabatan yang lebih dekat daripada gurami strain bluesaphire nomor 2, gurami strain jepang nomor 5 , 
dan gurami strain soang nomor urut 6. Pada individu gurami lainnya, terdapat perkembangan karakter yang lebih jauh antara delapan gurami soang dan tiga individu gurami jepang. Hal ini diperkirakan karena terjadinya percampuran gen antara nenek moyang gurami strain soang dan nenek moyang gurami strain jepang.

Secara keseluruhan terlihat adanya percampuran gen antarstrain ikan gurami sehingga dibutuhkan proses seleksi agar didapatkan strain ikan gurami yang unggul. Diharapkan strain ikan gurami yang unggul dapat meningkatkan produktivitas serta perkembangan budidaya ikan gurami, yang pada akhirnya dapat meningkatkan pendapatan petani gurami.

Dari hasil analisis software PAUP versi $4.0 \mathrm{bv} 10$ didapatkan nilai CI (Consistency Index) sebesar 0,6800. Homoplasy Index atau HI sebesar 0,3200 dan nilai RI atau Retention Index sebesar 0,8242. Menurut Kludge dan Farris (1969) dalam Donoghue dan Reet (2000) homoplasi dapat diketahui secara kuantitatif dengan menggunakan Consistency Index. Apabila nilai Consistency Index mendekati atau sama dengan 1 berarti dalam kladogram tersebut homoplasinya sangat rendah atau tidak ada sama sekali dan begitu juga sebaliknya.

Dharmayanti (2011) menjelaskan bahwa ketika sekuens nukleotida atau protein dari dua organisme yang berbeda memiliki kemiripan, maka mereka diduga berasal dari sekuens common ancestor atau nenek moyang. Penjajaran sekuens akan menunjukkan posisi sekuens yang tidak berubah atau conserved, dan sekuens yang berkembang atau divergent menjadi berbeda dari common ancestor. Kemena dan Notredame (2009) dalam Dharmayanti (2011) menjelaskan bahwa tujuan penjajaran sekuens ialah untuk mencocokkan karakter yang homolog, yaitu karakter yang dimiliki oleh nenek moyang yang sama. Fitch (1971) dalam Hidayat et al. (2008) mengatakan bahwa analisis filogenetik dapat dilakukan menggunakan pirantik lunak PAUP versi 4.0bv10 berdasarkan metode parsimoni. Semua pohon filogenetik yang terbentuk disimpan. Evaluasi pohon dilakukan menggunakan analisis bootsrap sebanyak 1.000 ulangan.

\section{K E S I M P U L A N}

Berdasarkan penelitian yang telah dilakukan, dapat diambil kesimpulan bahwa

1. Primer yang menghasilkan marka RAPD yang konsisten dan polimorfik pada beberapa strain ikan gurami adalah OPA-11, OPA-20, ОРAH-1, OPAH-08, dan OPAH-09.

2. Marka RAPD spesifik yang dapat digunakan untuk membedakan antarstrain ikan gurami ialah OPA20 ukuran 786 pb, OPA-20 ukuran 1.176 pb,
OPAH-08 ukuran 1.000 pb, dan OPAC-14 ukuran $1.607 \mathrm{pb}$.

3. Secara filogenetik, marka RAPD tidak dapat digunakan untuk menentukan hubungan kekerabatan genetik antarstrain ikan gurami dengan jelas.

\section{UCAPAN TERIMA KASIH}

Penulis mengucapkan terima kasih yang sebesarbesarnya kepada Proyek Riset Unggulan Kompetensi Unsoed (RUKU) atas dukungan dana yang diberikan bagi penelitian ini.

\section{AFT AR REFERENSI}

Allard RW. 1960. Principle of Plant Breeding. New York: Willey and Son. Inc.

Asih S, Nugroho E, Mulyasari. 2006. Penentuan keragaman genetik ikan batak (Tor sorro) dari Sumatera Utara dengan metode Analisis Random Amplifified Polymorphism DNA (RAPD). Balai Riset Perikanan Budidaya Air Tawar; Kumpulan Hasil Riset Tahun 2006.

Dharmayanti NLPI. 2011. Filogenetika molekuler: metode taksonomi organisme berdasarkan sejarah evolusi. Wartazoa. 21(1): 1-10

Dodgson JB, Cheng HH, Okimoto R. 1997. DNA marker technology: a revolution in animal genetics. Poultry Science. 76: 1108-1114.

Fitch WM. 1971. Toward defining the course of evolution: minimum change for a specific tree topology. Systematic Zoology. 20: 406416.

Hidayat T, Kusumawaty D, Kusdianti DD, Yati AA, Muchtar, Mariana D. 2008. Analisis filogenetik molekuler pada Phyllanthus niruri L. (Euphorbiaceae) menggunakan urutan basa DNA daerah Internal Transcribed Spacer (ITS). Jurnal Matematika dan Sains, 13(1): 16-21.

Iwan D. 2006. Budidaya Gurami. Jakarta: Penebar Swadaya.

Jain A, Bhatia S, Banga SS, Prakash S. 1994. Potential use of random amplified polymorphic DNA (RAPD), technique to study the genetic diversity in indian mustard (Brassica juncea) and its relationship to heterosis. Theoritical and Applied Genetics. 88: 116-122.

Kottelat M, Whitten AJ, Kartikasari SN, Wirjoatmodjo S. 1993. Freshwater Fishes of Western Indonesia and Sulawesi. Republic of Indonesia: Periplus ed Ltd.

Kludge AG, Farris JS. 1969. Quantitative phyletics and the evolution of anurans. Systematics Zoology. 18: 1-32.

Lestari E. 2011. Variasi genetik ikan sepat (Trichogaster trichopterus) di bagian hilir sungai karang rowo undaan kudus berdasarkan polimorfisme marka RAPD [Skripsi]. Universitas Jenderal Soedirman-Purwokerto.

Muneer PMA, Gopalakrishnan A, Musammilu KK, Mohindra V, Lal KK, Basheer VS, Lakra WS. 2009. Genetic variation and population structure of endemic yellow catfish, Horabagrus brachysoma (Bagridae) among three population of western ghat region using RAPD and microsatellite markers. Molecular Biology and Reproduction. 36: 1779-1791.

O’Brien SJ. 1991. Mammalian genome mapping: lessons and prospects. Current Opinion in Genetic Development. 1: 105111.

Sitanggang M, Sarwono B. 2007. Budidaya Gurami Edisi Revisi. Jakarta: Penebar Swadaya.

Welsh J, McClelland M. 1990. Fingerprinting genome using PCR with arbitary primers. Nucleic Acid Research. 18: 7213-7218.

William DS, Colome JS, Cano RJ. 1996. Schaum's Outline of Theory and Problems of Molecular and Cell Biology. USA: The McGrawHill.

Williams JGK, Kubelic AR, Livak JK, Ravalski JA, Tingey SV. 1990. DNA polymorphisms amplified by arbitary primer are useful as genetic marker. Nucleic Acid Research. 18: 6531-6539. 